July 2019

"Local labor impact of wind energy investment: an analysis of Portuguese municipalities"

Hélia Costa and Linda Veiga 


\title{
Local labor impact of wind energy investment: an analysis
}

\author{
of Portuguese municipalities*
}

\author{
Hélia Costa \\ Linda Veiga \\ Toulouse School of Economics ${ }^{\dagger} \quad$ University of Minho $\ddagger$
}

July 2019

\begin{abstract}
Investment in wind power has grown remarkably in the past decades in Portugal. Although economic development is an argument for investment incentive policies, little evidence exists as to their net impact on local-level unemployment. Using a panel of all 278 Portuguese mainland municipalities for the years 1997-2017, we assess the existence, distribution and duration of local level labor impacts of wind power investment. Our results show there are short term effects during the construction phase. We estimate a decrease of 0.05 percentage points in the total unemployment rate for each KW per capita installed. These effects are confined to unskilled labor and male workers. Further analysis of spatial interaction finds positive spatial spillovers for municipalities that are $30 \mathrm{~km}$ or less away but not farther, implying workers are willing to commute but not migrate. We find no evidence of sustained effects or impact during the operations and maintenance phase, despite both short and long term impacts in municipalities' revenues.
\end{abstract}

JEL classification: C23, H70, Q50

Keywords: Wind power, labor effects, panel data

\footnotetext{
*The authors thank Francois Cohen, Alexandra Gomes, Ralf Martin and participants of the Grantham Research Workshop at London School of Economics, the TSE Environmental winter seminars at the Toulouse School of Economics, the 4th IZA Workshop on Labor Market Effects of Environmental Policies, the EAERE 2017, and the FSR Climate Annual Conference for valuable comments. Hélia Costa acknowledges funding from the ESRC Centre for Climate Change Economics and Policy, from the European Communitys 7th Framework Program under Grant Agreement No. 308497 (RAMSES), from the ANR under grant ANR-17-EURE-0010 (Investissements dAvenir program), and from the IDEX Chair. Linda Veiga's work is financed by National Funds of the FCT Portuguese Foundation for Science and Technology within the project UID/ECO/03182/2019.

$\dagger$ Toulouse School of Economics, University of Toulouse Capitole, Toulouse, France. Address: Toulouse School of Economics, Manufacture des Tabacs, 21 Allée de Brienne, 31015 Toulouse, France. Email: helia.costa@tse-fr.eu

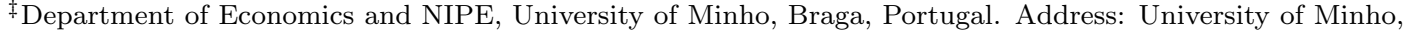
Campus de Gualtar, 4710-057 Braga, Portugal. Email: linda@eeg.uminho.pt
} 


\section{Introduction}

The aim of this paper is to evaluate the impact of wind power investments on the local labor market. Renewable energy has been a key part of the environmental strategy of the European Union to reduce $\mathrm{CO}_{2}$ emissions, as well as to increase energy independence and security. The climate and energy package set out the objective of raising the share of European Union energy consumption produced from renewable resources to $20 \%$ by 2020 . In addition to environmental objectives, the European Commission estimated that meeting this target could have a net effect of creating up to 417000 jobs by 2020 (Ragwitz et al., 2009). However, doubts remain as to whether these effects translate into an increase in overall employment - rather than a displacement of resources - as well as into effects at the local level rather than at the aggregate level only. This is of major importance to the local communities that house these projects, sometimes with negative impacts in terms of housing prices (Lang et al., 2014, Gibbons, 2015, Sunak and Madlener, 2016). We aim at assessing the existence, magnitude, duration, and distribution of effects of investment in renewables on total local employment, by performing a panel data analysis of the wind industry in Portuguese municipalities.

Portugal has made large investments in renewable energy, in particular wind power, in the past decades, despite the economic slowdown. In 2017 the wind share in total electricity demand in mainland Portugal was of 24.1\%(e2p Endogenous Energies of Portugal, 2017a). Total installed generating capacity increased from 27.22 megawatt (MW) in 1997 to $5332 \mathrm{MW}$ in 2017, making Portugal the country with the third highest kilowatt (KW) installed per $k m^{2}$ in the EU (e2p Endogenous Energies of Portugal, 2017a). Understanding local economic consequences of these investments is therefore important.

The Portuguese economy is highly energy intensive and has traditionally been especially dependent on imports of primary fossil fuels. Consequently, one of the main benefits of investment in renewables, and in particular in wind power, is to decrease the weight of these imports in national Gross Value Added. Additionally, the development of the wind industry is expected to increase competitiveness and contribute to the creation of jobs. Deloitte (2009) estimated that in 2008 the wind industry generated a total of 2200 direct and indirect jobs, expected to increase to 5850 by 2015 . The International Labor Organization predicts that, worldwide, one megawatt of wind energy could create between 0.43 and 2.51 jobs at the construction and manufacturing phase, and 0.27 during the operations and maintenance phase, with a mix of low, medium, and high skilled labor (ILO, 2011).

These project level or input-output studies that typically focus on gross impacts may not mea- 
sure the total net impact of wind investment. The overall impact of a wind park might be smaller than estimated by these studies if it displaces other kinds of investment, or larger if the macroeconomic impact resulting from the investment generates further employment. By performing an econometric analysis with historic data we can account for these effects and estimate the total net impact. Whether benefits are accrued at the local level and how they are determined and distributed are important questions for designing policy incentives to wind investment.

We perform the analysis for a panel of all the 278 Portuguese mainland municipalities for the years between 1997 and 2017. We study the impact of the installation of wind power in a given municipality on its unemployment rate, and distinguish between the construction phase, and the operations and maintenance phase. We further investigate how these impacts vary with the gender and educational levels of workers. Moreover, we explore the possibility of local spillovers between municipalities. Development in one region may affect employment in another through migration or indirect economic impacts (such as the increase in demand for goods and services). We use a distance decay matrix to address this possibility.

Finally, we further our understanding of the local economic impacts of wind energy investment by studying its effect on local governments' finances. Municipal revenues may increase in the short run because energy companies buy public land or in the long run because they rent land or pay taxes and other services.

Our identification strategy is based on the fact that the main determinants of the location of wind investment within the country, such as the wind energy potential for commercial turbines, orography, or slope of the land, are time invariant. They are thus captured by municipality level fixed effects. While incentive schemes for investment in wind power are strong determinants of the decision to invest, these are decided at the country or European level and implemented equally across municipalities, and are therefore captured by time fixed effects.

It is however possible that the central government, when granting permission for the construction of wind parks, gives preference to municipalities with lower income levels, in order to boost development there. In such a case, our estimations would be biased. While the granting process was traditionally non-restrictive and so based mainly on technical factors, we include growth of regional GDP in order to control for this possibility.

To the best of our knowledge only a few studies have performed similar analyses. ${ }^{1}$ Brown et al. (2012) perform a cross section econometric analysis of employment and income impacts of wind power installation using county total variation in wind power from 2000 to 2008. They find that

\footnotetext{
${ }^{1}$ Other studies have instead focused on country level impacts (eg. Inglesi-Lotz, 2016).
} 
personal income and employment increase $11000 \$$ and 0.5 jobs respectively per MW. Using a cross section variation of installed wind power from 2001 and 2011 in Texas counties, De Silva et al. (2016) find positive impacts of employment at the industry, but not at the county level, as well as modest income impacts. Xia and Song (2017a) use a similar method to estimate the impact of wind power development from 2005 to 2011 in Chinese counties on GDP, finding positive impacts. Panel data allows to surpass endogeneity issues by exploring within-region variation. Hartley et al. (2015) use monthly data to compare the employment impacts of wind and shale gas investments for a panel of counties in the state of Texas. They focus on the impact in the six months after turbines are installed and find no significant impact.

We find that wind power investment has a negative impact on unemployment levels during the construction and manufacturing phase. In particular, a 100MW increase in installed power leads to an average of 0.13 percentage point decrease in unemployment rates. ${ }^{2}$ This amounts to roughly 0.33 jobs per MW installed. Further exploring the distribution of impacts by gender and education levels, we find that these are felt mainly for male workers and unskilled labor i.e., for workers without a college education. Moreover, we find evidence of spatial spillovers between close by municipalities. An increase in installed power in municipalities of less than $30 \mathrm{~km}$ distance to a given municipality also decreases unemployment in the latter, during the construction phase. No effects were found for municipalities that are farther away $(50 \mathrm{~km}$ and $100 \mathrm{~km}$ ), indicating possible commuting journeys for work, but not migration.

Finally, we found no benefits for employment of wind power investment during the operations and maintenance phase nor any long term impacts, but we found both short and long term positive impacts of wind energy investment on total municipal revenues. These were driven specifically by short term increases in property revenues and long term increases in revenues with direct taxes and sale of goods and services.

Our findings have important implications for renewable investment incentive policies. First, they present for the first time a clear evaluation of the overall net impact of wind power investment in local level employment in Portugal, a country where extremely large investments were made. Despite the focus put on job creation, local employment impacts seem to be short lived. Second, they provide information on the distributional impacts of such policies. The short term unemployment local benefits are concentrated on male and unskilled workers. Finally, they offer an insight into the mechanisms behind these impacts. The absence of any longer term impacts, along with the low mobility of labor, could indicate that, if policy makers wish to

\footnotetext{
${ }^{2}$ More precisely, we estimate a 0.05 percentage points decrease in the unemployment rate for $1 \mathrm{KW}$ per capita installed.
} 
increase benefits to local labor markets, there might be a case for targeting education and skill development towards the needs of this new market, in order to fully take advantage of possible local labor benefits. The long term impact on municipality revenues we found does not seem to be successfully translated into higher municipal employment.

The remainder of the paper is organized as follows. Section 2 describes the evolution of wind investment in Portugal and its legal framework. Section 3 describes the econometric model, the empirical strategy, and the data. Section 4 presents and discusses the results, and Section 5 concludes the paper.

\section{Wind Energy in Portugal}

Renewable energy (RES) development has surged in the past decades in Portugal. It went from an installed capacity of $3579.5 \mathrm{MW}$ in 1990, mostly from large hydropower, to $13573.27 \mathrm{MW}$ in 2017, driven by large increases in wind power investment. In 2009, and in the context of the European Union's (EU) Renewable Energy Directive (Directive 2009/28/EC), Portugal committed in its National Action Plan to achieve 31\% of final consumption energy from renewable sources. Figure 1 shows the evolution of installed RES capacity in Portugal.

Figure 1: Evolution of installed RES capacity in Portugal

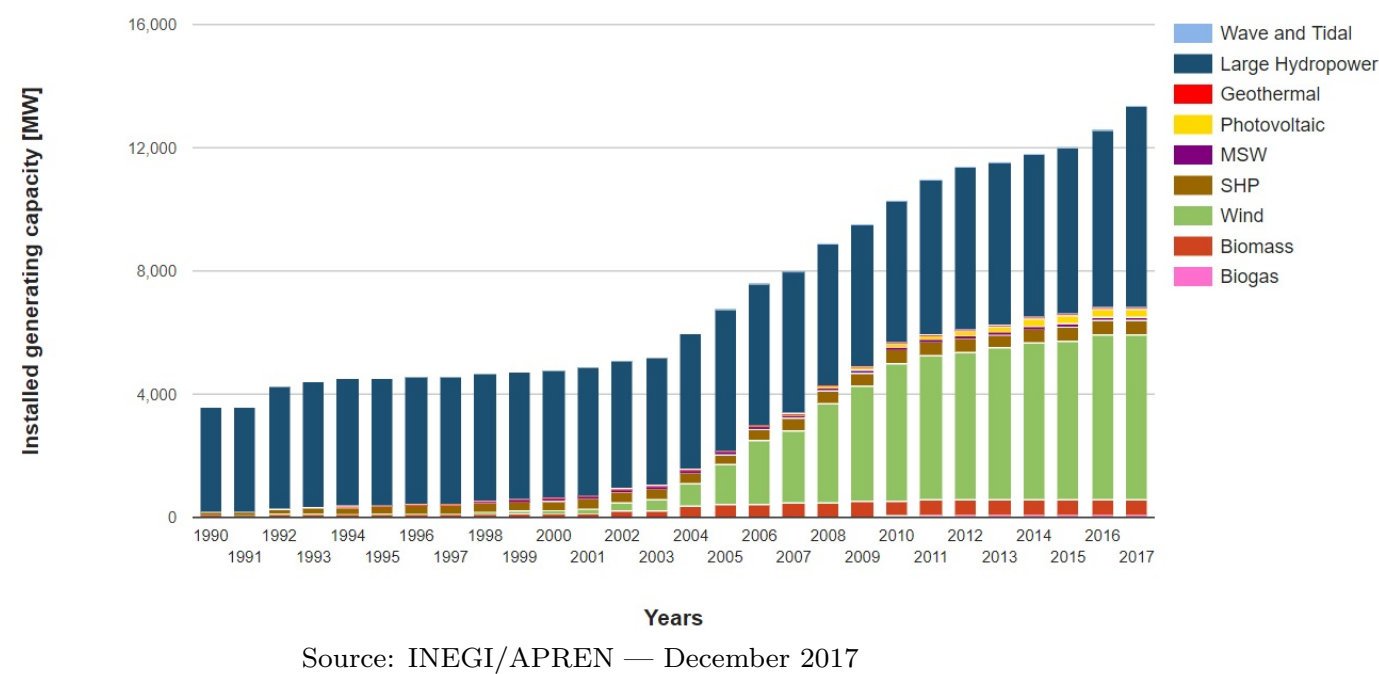

Legislation guaranteeing grid access for independent power producers using RES came into force in 1988 (Decree-Law 188/88 and Decree-Law 189/88). It covered only small hydropower, but in 1995 it was extended to cover other sources such as wind power (Decree-Law 313/95) and 
a system of feed-in-tariffs was introduced. Limited knowledge of wind resource potential and wind technology in Portugal rendered investment in wind power very modest during the 1990's (Bento and Fontes, 2014). The lack of clarity of the process of connection to the grid until 2001 further contributed to this (Peña et al., 2017). The development of new wind technology in Europe, coupled with a favorable Portuguese and European regulatory context, led to the takeoff of wind power investment in the late nineties.

A series of initiatives were meant to stimulate renewable electricity production and regulate the process more clearly. The system of feed-in-tariffs was revised in 1999 (Decree-Law 168/99) and 2001 (Decree-Law 339-C/2001 and Decree-Law 312/2001) to account for avoided costs of investing in conventional power plants and differentiated between technologies, with the first 2000 hours of wind energy production each year being paid EUR $0.082 / \mathrm{KWh}^{3}{ }^{3}$ The same documents simplified the license-granting process for grid access and a special tax of $2.5 \%$ of total wind revenue to be paid to local municipalities was introduced, with the aim of increasing local benefits. ${ }^{4}$ With the same aim, in the 2005 process of releasing a tender for $1800 \mathrm{MW}$ of wind power, in addition to technical requirements, a condition for being granted tendering conditions was working with local manufacturing companies. Additional conditions included limiting import of turbines, contributing to research and development, and pursuing the transfer of technology to Portugal. As a result national incorporation of inputs rose from $20 \%$ to $100 \%$ for this tender (Bento and Fontes, 2014).

In the context of the Portuguese economic crisis, and in particular with the 2011 intervention by the International Monetary Fund (IMF), incentives for wind power development such as feedin-tariffs were slowly revised, and wind power capacity started to grow slower.

Nevertheless, installed wind power generating capacity increased from $27.22 \mathrm{MW}$ in 1997 to $5332 \mathrm{MW}$ in 2017, with Portugal having the third highest KW installed per $\mathrm{km}^{2}$ in the EU (e2p Endogenous Energies of Portugal, 2017a). In 2017 the wind share in total electricity demand in Portugal was of 24.1\%(e2p Endogenous Energies of Portugal, 2017a).

Permission for the exploration of wind energy is granted by the central government, ${ }^{5}$ and the main determinants of location of wind parks are set out in Section 3.3, the most important of those being wind potential and access to the grid.

Figure 2 overlays the location of all existing wind parks in 2017 on a map of the wind potential

\footnotetext{
${ }^{3}$ This tariff is reduced by 200 hour blocks until a minimum of EUR 0.04/KWh after 2600 hours).

${ }^{4}$ The special tax was to be applied not only to new wind plants but also for existing ones, if bilateral agreements between wind plant developers and municipalities did not foresee higher sums being paid.

${ }^{5}$ Specifically, the Directorate General for Energy and Geology (DGEG) either grants access directly for wind parks or grid connection licences may be granted through a public tender, where specific conditions apply. Most licences where awarded in public tenders in the years 2001, 2003, and 2005 (Peña et al., 2017).
} 
of continental Portugal, as measured by the total number of annual hours of energy production corresponding to the capacity of a commercial wind turbine. ${ }^{6}$

Figure 2: Wind parks and potential

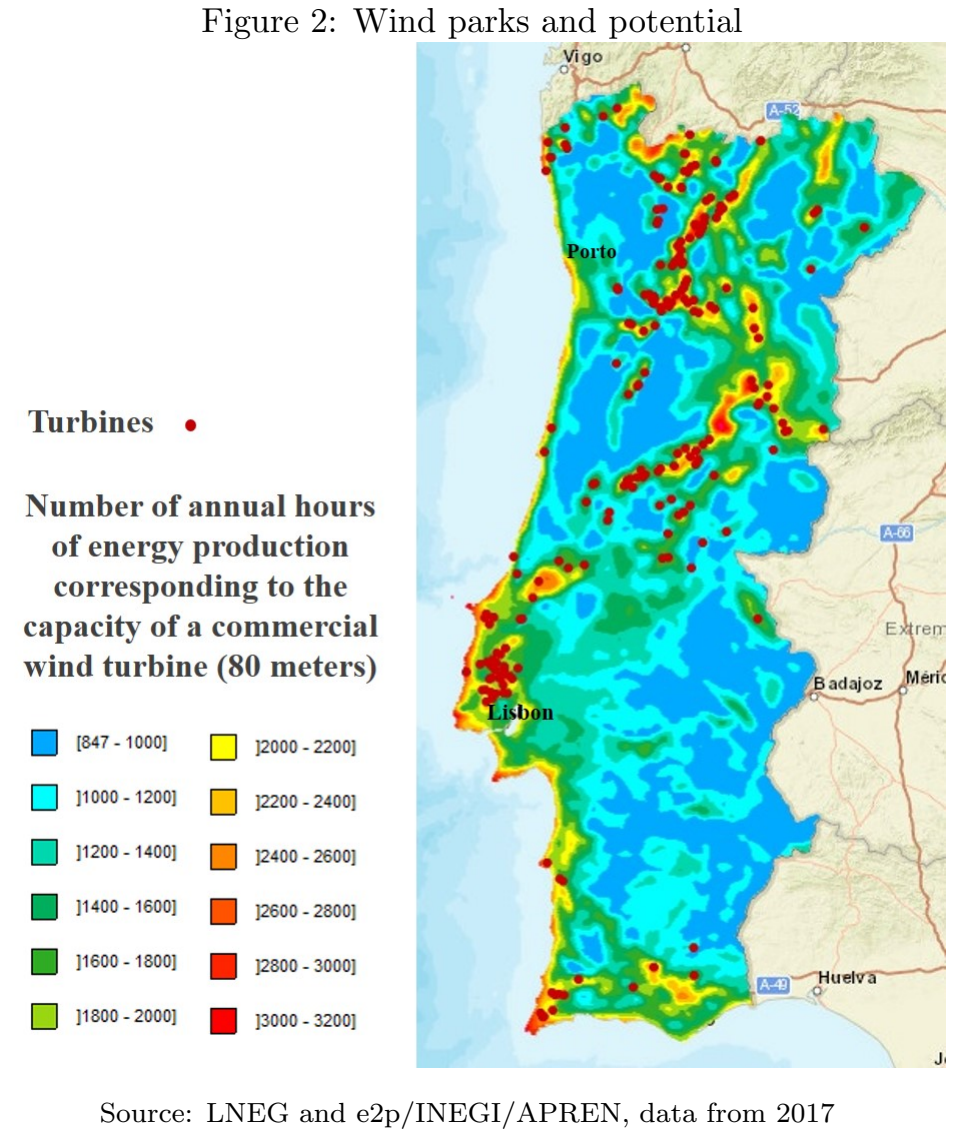

\section{Empirical Model}

\subsection{Empirical Strategy}

The aim of the analysis is to investigate municipality level effects of investment in wind power in Portugal. Our dependent variable is the unemployment rate at the municipal level, the estimation of which is described in Section 3.2. Our main independent variable of interest is the amount of wind power installed in municipality $i$ in a given year, in KW per capita. This variable captures effects of installation of a wind park in the year it starts producing energy, and therefore relates to the first year of the operations and maintenance phase. In order to account for the effects of the construction and manufacturing phase, we use a variable measuring the amount of power per capita installed in the following year. This is because it usually takes

\footnotetext{
${ }^{6}$ Further information on the use of this variable and its source is presented in Section 3.
} 
between 6 months and a year to build a wind park. ${ }^{7}$ We also experiment with past lags, in order to investigate further effects of maintenance and operations that might only have an impact in the future. ${ }^{8}$

The basic empirical specification is thus given by:

$$
\text { unemp }_{i t}=\alpha_{1}+\gamma_{1} \text { power }_{i t+1}+\gamma_{2} \text { power }_{i t}+\alpha_{2} X_{i t}+\eta_{i}+\rho_{t}+\epsilon_{i t}
$$

where $u_{n e m p}$ is the unemployment rate in municipality $i$ year $t$, power $_{i t+1}$ is the total power per capita installed and starting operations in municipality $i$ year $t+1$ (construction phase), power $_{i t}$ the total installed power per capita to enter into functioning in municipality $i$ year $t$ (maintenance phase), and $X_{i t}$ is a vector of economic and demographic variables affecting unemployment in municipality $i$ in year $t$. Finally, $\eta_{i}$ is a municipality individual fixed effect, $\rho_{t}$ a year fixed effect, and $\epsilon_{i t}$ the error term.

Included in vector $X_{i t}$ are growth of Gross Domestic Product (GDP) by NUTS3 region, in real per capita terms and in the previous year $\left(\Delta G D\right.$ Preg $\left.g_{i t-1}\right)$, that captures changes in regional economic conditions, and total spending by municipalities in the previous year, in real per capita terms $\left(\right.$ totexp $\left._{i-1}\right)$, because past expenditures can stimulate employment. These two variables are lagged one period in order to avoid endogeneity issues. ${ }^{9}$ Additionally, it includes two demographic variables (population density, denspop $p_{i t}$, and share of population under 15 years old, young $g_{i t}$ ). In order to account for possible impacts of urbanization we estimate the model including the interaction between installed power and a dummy variable equal to one if a municipality includes at least one city, city .

We additionally investigate the impact of wind investment for skilled versus unskilled labor. As a proxy for the level of skill of a job, we use the level of completed education of the worker. We thus repeat the estimation using as the dependent variable respectively the estimated unemployment rate for workers with one, two, or three levels of basic (pre-high school) education, corresponding to 4,6 , and 9 years of schooling, with secondary (high school) education, and finally, with a university degree. ${ }^{10}$ We also investigate whether unemployment effects depend on gender, by

\footnotetext{
${ }^{7}$ In Portugal, depending on the size of the park and the economic conjuncture, it might take even longer. To account for this we also study effects more than one year before the wind park starts production.

${ }^{8}$ Furthermore, we use the accumulated installed $\mathrm{KW}$ in each municipality, to verify if there are sustained long term impacts of installing wind energy in municipalities' unemployment. Given that the main interest of the paper is the immediate effect of wind investment, these results are presented in Appendix B.

${ }^{9}$ NUTS3 regions include a varying number of municipalities. A measure of GDP is not available at the municipal level.

${ }^{10}$ The third level of basic education was the level of mandatory education in Portugal until 2009, when it changed to secondary (high school) education.
} 
testing the impacts for female and male unemployment.

Finally, employment in municipality $i$ may be affected by the power installed in neighboring municipalities. For example if there is sufficient labor mobility or if development in neighboring municipalities creates demand for good and services that spill over into municipality $i$, then investment by neighbors might have a positive effect in own employment. It may also happen that development in neighboring municipalities diverts investment away from municipality $i$, thereby impacting negatively its levels of employment.

We account for this by including in the regression a measure of the power installed in neighboring municipalities. We weight this power by a matrix based on geographic proximity, such that closer neighbors have a larger effect in a given municipality's unemployment rate. In order to define this matrix, a commonly used method is to assign weights based on binary contiguity. This would imply that municipalities sharing a border are weighted equally, and others are not considered neighbors. Since Anselin (1988) argues this method may not account for the full degree of spatial interaction in the data, we follow Cliff and Ord (1981) and define neighbors according to the geographical distance between them. Specifically, we define neighbors according to the Euclidean distance between the centers of the municipalities, and construct the weights as the inverse of this measure. We then standardize the weights $w_{i} j$ such that for a given municipality $i, \sum_{j} w_{i j}=1$. More discussion on the appropriate choice of economic neighbors in the context of Portuguese municipalities can be found in Costa et al. (2015).

We first consider all municipalities neighbors, with a lower weight assigned the further away they are. We then limit municipalities that are considered neighbors to those that are $x$ or less kilometers apart, with $x=30, x=50$, and $x=100 \mathrm{~km}$. The former aims at capturing commuting travelling for work, and the two latter possible migration for work effects.

Hence the weight of municipality $j$ relative to municipality $i, w_{i j}$, is defined as:

$$
w_{i j}=\frac{\frac{1}{\operatorname{dist}_{i j}}}{\sum_{j} \frac{1}{\text { dist }_{i j}}}
$$

in the case all municipalities are considered neighbors, or

$$
w_{i j}= \begin{cases}\frac{\frac{1}{d i s t_{i j}}}{\sum_{j} \frac{1}{d i s t_{i j}}} & \text { if } 0<d_{i j} \leq x k m \\ 0 & \text { otherwise }\end{cases}
$$

in the case only municipalities that are less than a certain distance apart are considered neighbors. Thus, Eq. (1) is augmented with the term $W_{\text {power }}{ }_{j t}=\sum_{j \neq i} w_{i j t}$ power $_{j t}$, where $j$ are 
municipality $i$ 's neighbors, becoming:

$$
\text { unemp }_{i t}=\alpha_{1}+\gamma_{1} \text { power }_{i t+1}+\delta \text { Wpower }_{j t+1}+\alpha_{2} X_{i t}+\eta_{i}+\rho_{t}+\epsilon_{i t}
$$

where the other variables remain unchanged from Eq. (1) and where we focus on the construction and manufacturing period. ${ }^{11}$

\subsection{Data and Sources}

The dataset used covers all 278 Portuguese mainland municipalities for the period of 1997-2017 for a total of 5832 observations.

Table 1: Summary statistics

\begin{tabular}{lccccc}
\hline \hline \multicolumn{1}{c}{ Variable } & Mean & Std. Dev. & Min. & Max. & N \\
\hline Unemployment rate & 6.722 & 2.699 & 1.38 & 18.477 & 5832 \\
Female unemp. & 8.32 & 3.418 & 1.606 & 26.275 & 5554 \\
Male unemp. & 5.321 & 2.472 & 0.589 & 17.459 & 5554 \\
Unemployment (1st) & 11.795 & 29.718 & 0.265 & 2113.814 & 5832 \\
Unemployment (2nd) & 15.907 & 86.02 & 0.26 & 6309.206 & 5832 \\
Unemployment (3rd) & 12.384 & 63.135 & 0.117 & 4633.634 & 5832 \\
Unemployment (Sec) & 12.388 & 65.573 & 0.098 & 4826.965 & 5832 \\
Unemployment (Uni) & 7.615 & 59.495 & 0 & 4394.658 & 5823 \\
Power installed (KW) & 878.969 & 6970.495 & 0 & 222000 & 5832 \\
Power installed (KW pc) & 0.073 & 0.765 & 0 & 32.123 & 5832 \\
Power accum. (KW pc) & 0.778 & 2.964 & 0 & 43.114 & 5832 \\
NEPS & 1355.592 & 368.071 & 665.161 & 2537.657 & 5832 \\
Population & 35706.598 & 57252.778 & 1634 & 606480 & 5832 \\
Population density & 306.178 & 856.243 & 4.017 & 7670.162 & 5832 \\
City & 0.424 & 0.494 & 0 & 1 & 5832 \\
Weight of young (<15) & 13.703 & 2.686 & 4.841 & 23.878 & 5832 \\
Weight of elderly (> 65) & 22.343 & 6.358 & 8.116 & 45.568 & 5832 \\
GDP growth NUTS3 pc & 1.416 & 3.568 & -15.645 & 25.94 & 5832 \\
Total spending pc & 1064.109 & 538.782 & 177.106 & 8606.569 & 5832 \\
Total revenue pc & 1069.657 & 539.903 & 270.275 & 8601.380 & 5832 \\
\hline
\end{tabular}

Table 1 summarizes the data. ${ }^{12}$ The total unemployment rate varies between a minimum of 1.4 and a maximum of 18.5, and is calculated based on the number of people enrolled in the

\footnotetext{
${ }^{11} \mathrm{~A}$ similar analysis for the maintenance period does not yield any significant results and is not presented in the paper but is available upon request.

${ }^{12}$ Summary statistics by two groups, one with all 171 municipalities that never had power installed, and one with all 108 municipalities that did, is available in Appendix A.
} 
Portuguese centers of employment (IEFP), weighted by the total number of working age inhabitants, where the total number of working age inhabitants is calculated as the total population of the municipality minus those aged 15 years old or younger, and those aged 65 or older. A graph depicting the annual sum of unemployment rates across municipalities as well as the annual sum of installed power is presented in Appendix A. The unemployment rate is followed by two variables that are estimates of the unemployment rate by gender and four that measure unemployment by education.

Unemployment by gender is proxied by weighting the number of unemployed female and male respectively by the total number of female and male inhabitants, irrespective of whether they are of working age or not. ${ }^{13}$ The number of unemployed people by gender is only available until 2016 and as such these variables have only 5554 observations. Similarly, the total number of people with different levels of education, again whether of working age or not, by municipality was used to estimate a rough measure of unemployment rate by level of education. ${ }^{14}$

The following three variables correspond respectively to installed power in $\mathrm{KW}$, installed power in KW per capita, and to total installed power accumulated by a given municipality in a given year. Data on the exact location of wind parks, time of production start, and capacity of turbines was retrieved from e2p Endogenous Energies of Portugal (2017b), with permission from the institution. Whenever a wind power plant was installed between two municipalities the total power was assumed to be divided equally between these municipalities. Installed power varies greatly, between a minimum of zero and a maximum of $222 \mathrm{MW}$ installed in a given year and a given municipality. There was a total of 237 increases in power installed in the period of analysis. All power installed in onshore. ${ }^{15}$

NEPS stands for the number of annual hours of energy production corresponding to the capacity of a commercial wind turbine ( 80 meters), and measures the energy productive capacity of the wind. The variable is presented here as an average by municipality. This information was ceded by the Portuguese National Laboratory of Energy and Geology (LNEG).

Total GDP per capita by NUTS3, used to calculate its growth rate, was retrieved from the National Institute of Statistics (INE). Data on municipalities' local accounts was obtained from the DGAL's annual publication Municipal Finances (DGAL, 1986-2017). These variables were deflated using the 2017 consumer price index. Data on the consumer price index, municipal

\footnotetext{
${ }^{13}$ The number of people by age and by gender is not available.

${ }^{14}$ Specifically, the number of people with secondary education was used to estimate the unemployment rate for the first four categories of unemployed, since there was no information on number of inhabitants with first, second, and third levels of basic education, and the number of people with a university degree for the latter.

${ }^{15}$ An experimental offshore wind turbine was constructed in 2011 and deactivated in 2016. For the purpose of homogeneity it is left out of our analysis.
} 
population, the proportions of population under 15 and over 65 , as well as the number of cities were collected from the National Institute of Statistics.

\subsection{Identification Strategy}

Wind investment in Portugal has grown remarkably mainly due to the national and European level regulation described in Section 2. This regulation is decided at the national or international (European) level and implemented equally across municipalities, and therefore changes to it are captured by time fixed effects. Our identification strategy is based on the fact that within country determinants of wind power location are mainly time-invariant. Casadinho (2014) distinguishes three set of criteria for the location of wind parks: location criteria, accessibility criteria, and restrictions. The former includes the energy potential of the wind, or orography, the second set electric grid accessibility and general accessibility, and the latter includes restrictions imposed, such as environmentally protected areas, areas with high slopes, areas with existing wind parks, and areas with high population density. Of these, population density might vary considerably over time and so, to avoid omitted variable bias, we include it in our analysis.

Figure 3 shows the location of all operational wind turbines in Portugal, as well as the average energy potential of wind by municipality, measured by the number of annual hours equivalent to the nominal power of a commercial turbine, one of the main determinants of wind park location (Casadinho, 2014). 


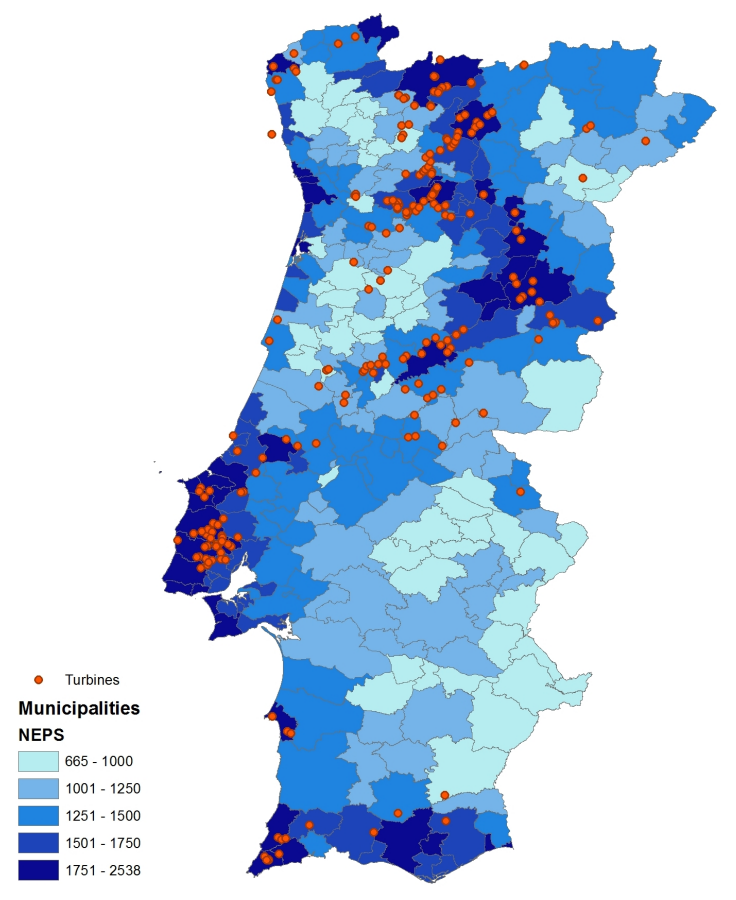

Figure 3: Turbine location and municipality wind capacity (NEPS)

Permission is granted by the government for the exploration of wind energy. While the granting process was traditionally non-restrictive and so based mainly on technical factors, it is possible that the central government gives preference to investment in municipalities with lower income or employment levels, in order to boost development here. In such a case, our estimations would be biased. Given that measures of wind potential of each municipality are mostly time invariant, we cannot use this as an instrument and still use fixed effects to control for all municipality-level unobservables. We instead include annual growth of regional GDP in order to account for this possibility. We lag this variable one period in order to avoid endogeneity issues. The exclusion of this variable does not change results. ${ }^{16}$

Table 2 further investigates possible endogeneity of investment in wind energy. The dependent variable in regressions (1)-(4) is wind investment in municipality $i$ in year $t$. The first three columns investigate the possible impact of past levels of unemployment in the choice of location of wind parks, showing no significant effect. The fourth column investigates the impact of past levels of GDP growth in the choice of investment, again with no significant impact. ${ }^{17}$

Finally, column five shows the impact of population density $\left(\right.$ denspop $\left._{i}\right)$ and of the energy poten-

\footnotetext{
${ }^{16}$ We furthermore include the average unemployment rate of the 4 years prior to construction without a change in results, but decide against this due to endogeneity issues.

${ }^{17}$ This is consistent with the analysis of Xia and Song (2017b) for Chinese municipalities.
} 
Table 2: Further tests for identification

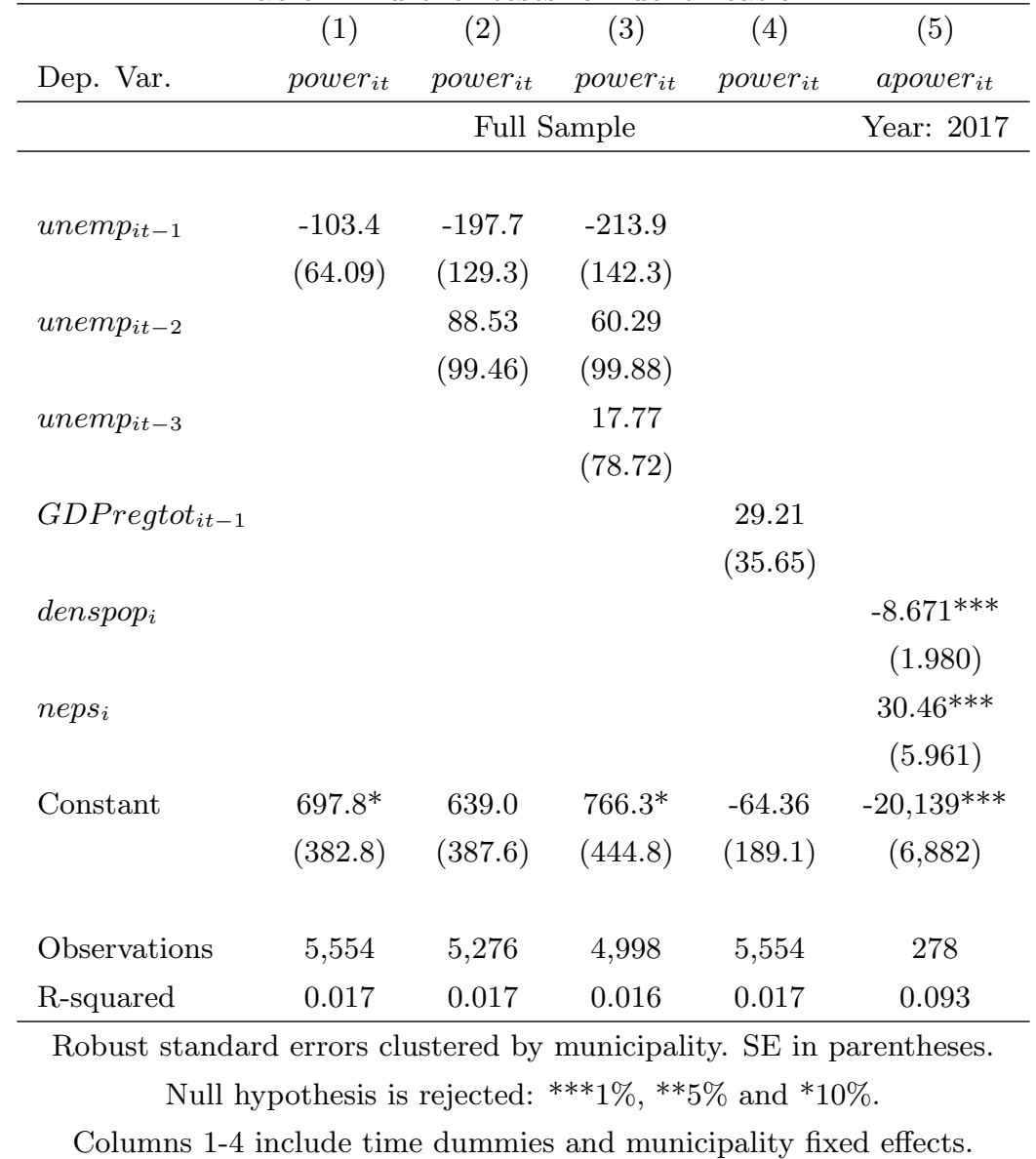

tial of wind by municipality, measured by the number of annual hours equivalent to the nominal power of a commercial turbine $\left(n e p s_{i}\right)$. The dependent variable in this regression is the total power accumulated per capita by 2017 , as the energy potential is time invariant. ${ }^{18}$ Both these variables have a significant impact on the choice of investment in wind energy. In line with the theory (Casadinho, 2014), population density negatively affects investment levels, while the energy potential affects it positively.

\section{Results}

Our empirical results are presented in Tables 3-5. Table 3 presents the results of the main empirical specification, and in Section 4.1 we justify our econometric estimation technique. In Table 4 we present the results for disaggregated unemployment rates, and in Table 5 we present the results of the spatial analysis based on geographic proximity. Throughout the analysis

\footnotetext{
${ }^{18}$ The population density used is also that of 2017 , since this does not vary significantly.
} 
we implement the same estimation method and include similar control variables to facilitate comparison. Finally, Section 4.4 discusses the results and further investigates local level impacts of investment.

\subsection{Wind Investment and Unemployment Rate}

The main results are presented in Table 3. Columns (1)-(3) present the estimation of Eq.(1) by ordinary least squares (OLS), random effects (RE) and finally fixed effects (FE). A Breush-Pagan test indicates the presence of heteroskedasticity so we use robust standard errors, clustered by municipality in all equations. ${ }^{19}$

Table 3: Effects on total unemployment rate

\begin{tabular}{|c|c|c|c|c|c|c|c|}
\hline & $(1)$ & $(2)$ & (3) & (4) & (5) & (6) & (7) \\
\hline Estimation & OLS & $\mathrm{RE}$ & $\mathrm{FE}$ & $\mathrm{FE}$ & $\mathrm{FE}$ & $\mathrm{FE}$ & $\mathrm{FE}$ \\
\hline power $_{i t+1}$ & $\begin{array}{c}-0.0831^{* * *} \\
(0.0304)\end{array}$ & $\begin{array}{c}-0.0502^{* * *} \\
(0.0150)\end{array}$ & $\begin{array}{c}-0.0495^{* * *} \\
(0.0151)\end{array}$ & $\begin{array}{c}-0.0511^{* * *} \\
(0.0153)\end{array}$ & $\begin{array}{c}-0.0497^{* * *} \\
(0.0156)\end{array}$ & $\begin{array}{c}-0.0419 * * * \\
(0.0148)\end{array}$ & $\begin{array}{c}-0.0532 * * * \\
(0.0154)\end{array}$ \\
\hline power $_{i t}$ & $\begin{array}{l}-0.0275 \\
(0.0347)\end{array}$ & $\begin{array}{c}-0.000190 \\
(0.0240)\end{array}$ & $\begin{array}{c}-4.65 \mathrm{e}-05 \\
(0.0240)\end{array}$ & $\begin{array}{c}-0.000685 \\
(0.0241)\end{array}$ & $\begin{array}{c}-0.000195 \\
(0.0238)\end{array}$ & $\begin{array}{l}0.00957 \\
(0.0248)\end{array}$ & $\begin{array}{c}0.000118 \\
(0.0240)\end{array}$ \\
\hline$\Delta G D P r e g_{i t-1}$ & $\begin{array}{c}0.0222 \\
(0.0164)\end{array}$ & $\begin{array}{c}-0.0199 * * \\
(0.00889)\end{array}$ & $\begin{array}{c}-0.0228^{* *} \\
(0.00908)\end{array}$ & & $\begin{array}{c}-0.0242^{* * *} \\
(0.00917)\end{array}$ & $\begin{array}{l}-0.0163^{*} \\
(0.00866)\end{array}$ & $\begin{array}{c}-0.0229 * * \\
(0.00910)\end{array}$ \\
\hline expend $_{i t-1}$ & $\begin{array}{c}0.920 * * * \\
(0.242)\end{array}$ & $\begin{array}{l}-0.245 \\
(0.154)\end{array}$ & $\begin{array}{c}-0.293^{*} \\
(0.166)\end{array}$ & $\begin{array}{l}-0.304^{*} \\
(0.167)\end{array}$ & & $\begin{array}{l}-0.229 \\
(0.161)\end{array}$ & $\begin{array}{c}-0.293^{*} \\
(0.166)\end{array}$ \\
\hline denspop $_{i t}$ & $\begin{array}{c}0.000173 \\
(0.000124)\end{array}$ & $\begin{array}{c}0.000126 \\
(0.000116)\end{array}$ & $\begin{array}{l}-0.000916 \\
(0.000795)\end{array}$ & $\begin{array}{l}-0.000903 \\
(0.000795)\end{array}$ & $\begin{array}{l}-0.000860 \\
(0.000834)\end{array}$ & $\begin{array}{c}-0.00103 \\
(0.000684)\end{array}$ & $\begin{array}{l}-0.000917 \\
(0.000795)\end{array}$ \\
\hline young $_{i t}$ & $\begin{array}{c}0.192^{* * *} \\
(0.0482)\end{array}$ & $\begin{array}{c}-0.174^{* * *} \\
(0.0482)\end{array}$ & $\begin{array}{c}-0.229 * * * \\
(0.0549)\end{array}$ & $\begin{array}{c}-0.224^{* * *} \\
(0.0549)\end{array}$ & $\begin{array}{c}-0.221^{* * *} \\
(0.0547)\end{array}$ & & $\begin{array}{c}-0.229 * * * \\
(0.0549)\end{array}$ \\
\hline old $_{i t}$ & & & & & & $\begin{array}{c}0.0723^{* *} \\
(0.0332)\end{array}$ & \\
\hline city $_{i t}$ & & & & & & & $\begin{array}{l}-0.0578 \\
(0.285)\end{array}$ \\
\hline city $_{i t} *$ power $_{i t+1}$ & & & & & & & $\begin{array}{c}69.31 \\
(60.81)\end{array}$ \\
\hline Constant & $\begin{array}{c}2.318^{* * *} \\
(0.850)\end{array}$ & $\begin{array}{c}8.975^{* * *} \\
(0.799)\end{array}$ & $\begin{array}{c}10.16^{* * *} \\
(0.898)\end{array}$ & $\begin{array}{c}10.02^{* * *} \\
(0.900)\end{array}$ & $\begin{array}{c}9.796^{* * *} \\
(0.866)\end{array}$ & $\begin{array}{c}5.203^{* * *} \\
(0.655)\end{array}$ & $\begin{array}{c}10.19^{* * *} \\
(0.904)\end{array}$ \\
\hline Observations & 5,276 & 5,276 & 5,276 & 5,276 & 5,276 & 5,276 & 5,276 \\
\hline R-squared & 0.312 & & 0.578 & 0.577 & 0.577 & 0.570 & 0.578 \\
\hline No of units in FE & & 278 & 278 & 278 & 278 & 278 & 278 \\
\hline
\end{tabular}

Robust standard errors clustered by municipality. Standard errors in parentheses.

Significance level for which the null hypothesis is rejected: ${ }^{* * *} 1 \%,{ }^{*} 5 \%$ and ${ }^{*} 10 \%$.

All estimations include time fixed effects.

The OLS results are expected to be biased, as they fail to account for individual effects, but they are presented for the sake of comparison. A Breusch and Pagan Lagrange-multiplier test

\footnotetext{
${ }^{19}$ With the exception of the spatial analysis, where we cluster them at the NUTS3 region level.
} 
for random effects gives preference to RE over OLS and finally, a Hausman specification test gives preference to FE over RE, so we use FE throughout our estimations. All equations include time fixed effects to capture all variables affecting all municipalities at the same time. Standard errors are presented in parenthesis.

Column (3) presents the results for the basic specification, testing effects during the construction and maintenance phases. The coefficient measuring the effect of wind power installation during the construction phase, power $_{i t+1}$, is negative and significant at a $1 \%$ level. In particular, it means that a $1 \mathrm{KW}$ per capita installed decreases unemployment in a given municipality by 0.05 percentage points during the construction phase. Taking into account average population and average unemployment rates by municipality, this translates in an average effect of around 0.3 jobs per MW installed, in line with previous estimations. The coefficient measuring the impact in the maintenance phase, power $_{i t}$, is not statistically significant.

As expected, the more dynamic the region where the municipality is (ie, the higher the regional GDP growth, $\Delta$ GDPregion $_{i t}$ ), and the higher municipal public expenditures are (expend ${ }_{i t-1}$ ), the lower the unemployment rate is. ${ }^{20}$ The coefficients measuring the number of cities and population density are not statistically significant. Finally, the larger the share of young population below working age the lower unemployment.

Columns (4) and (5) present the results respectively excluding regional GDP growth and municipal public expenditures, without changes in the results. Column (6) uses the weight of population over 65 years of age $\left(\right.$ old $\left._{i t}\right)$ instead of the weight of young population, ${ }^{21}$ again without affecting results. Finally, column (7) presents an estimation including the interaction between the number of cities and the variable measuring the power being installed. Although the variable is not statistically significant, it is positive, indicating the effect of wind power investment could be higher in rural areas.

Estimations of effects two years before, to account for the fact that it might take longer than a year to build a wind park, and one and two years after a wind park starts producing, as well as long term impacts of investment in power plants are presented in Table B.1 in Appendix B. The latter is measured by the coefficient of the power accumulated by a given municipality in a given year, per capita, Apower ${ }_{i t}$. None of these coefficients are statistically significant.

\footnotetext{
${ }^{20}$ Municipal expenditures per capita are in thousands in all estimations where expend $d_{i t-1}$ is an explanatory variable to make coefficient reading easier.

${ }^{21}$ The two cannot be included at the same time since they are very highly correlated $(-0.85)$.
} 


\subsection{Distribution of Impacts by Type of Labor}

We next focus on the distribution of the impacts on employment over gender and workers estimated skill levels. As described in Subsection 3.2, to have a proxy for unemployment rates by gender we use the number of unemployed people of each gender over the total population of the municipality by gender. We distinguish unemployment for workers with the first, second, and third level of basic education (from first to ninth grade), workers that have graduated from high school, and workers with university degrees. We proxy for unemployment rates by using the total number of inhabitants with secondary and university education to weight the number of unemployed people by education level. The magnitude of these estimations are therefore not directly comparable to those of Table 3, since that used the number of working age population only.

Table 4 presents the results regarding impacts by gender and education levels. The results in columns (1) and (2) show no significant impact for female workers, but only for male workers in the year before the wind plant starts producing, consistent with the impact being felt during the construction phase. ${ }^{22}$ There is a significant reduction of unemployment during the construction phase for workers with all three levels of basic education (columns (3)-(5)). The third level of basic education was the mandatory level of education in Portugal, during which all the population receives the same type of education, until 2012 when secondary education became the mandatory level (Law 85/2009). These are therefore likely to be employees performing unskilled labor. There is also an impact for workers with secondary education, significant at a $10 \%$ confidence level, and no impact at the level of workers with a university degree. There are no effects during the maintenance phase for any of the education levels. An ILO report (ILO, 2011) predicts increased demand of labor stemming from wind development for all skill levels, so these results might indicate a skill gap in the Portuguese labor market. It is possible that if skilled labor is not available locally, developers import it from other countries otherwise. ${ }^{23}$ If the operations and maintenance phase requires more skilled labor, this could help explain the lack of a significant impact locally at this stage.

\footnotetext{
${ }^{22}$ In 2014 women made up around $6 \%$ of all construction work employment (INE, 2015).

${ }^{23}$ Alternatively, they could import it from neighboring municipalities. A spatial analysis for the maintenance phase, available from the author, shows that this is not the case.
} 
Table 4: Effects on different unemployment rates

\begin{tabular}{|c|c|c|c|c|c|c|c|}
\hline & (1) & $(2)$ & (3) & (4) & (5) & (6) & (7) \\
\hline Dep. Variable & Women & Men & 1 & 2 & 3 & $\mathrm{Sec}$ & Uni \\
\hline \multirow[t]{2}{*}{ power $_{i t+1}$} & -0.0287 & $-0.0465^{* * *}$ & $-0.167 * *$ & $-0.514^{* *}$ & $-0.510^{* *}$ & $-0.371^{*}$ & -0.294 \\
\hline & $(0.0271)$ & $(0.0160)$ & $(0.0654)$ & $(0.224)$ & $(0.202)$ & $(0.217)$ & $(0.254)$ \\
\hline \multirow[t]{2}{*}{ power $_{i t}$} & 0.0234 & -0.0116 & -0.120 & -0.302 & -0.194 & -0.196 & -0.00449 \\
\hline & $(0.0331)$ & $(0.0230)$ & $(0.0747)$ & $(0.210)$ & $(0.183)$ & $(0.143)$ & $(0.103)$ \\
\hline \multirow[t]{2}{*}{$\Delta G D P r e g_{i t-1}$} & -0.0110 & $-0.0215^{* *}$ & 0.0843 & 0.0609 & 0.0823 & 0.0808 & 0.0106 \\
\hline & $(0.0102)$ & $(0.00949)$ & $(0.0858)$ & $(0.247)$ & $(0.211)$ & $(0.220)$ & $(0.234)$ \\
\hline \multirow[t]{2}{*}{ expend $_{i t-1}$} & $-0.831^{* * *}$ & -0.0807 & -1.245 & -5.029 & -1.423 & -1.971 & -0.504 \\
\hline & $(0.286)$ & $(0.124)$ & $(1.077)$ & $(3.326)$ & $(2.420)$ & $(2.500)$ & $(2.196)$ \\
\hline \multirow[t]{2}{*}{ denspop $_{i t}$} & 0.000781 & $-8.17 \mathrm{e}-05$ & 0.000855 & 0.00969 & 0.00485 & 0.00602 & 0.00370 \\
\hline & $(0.00161)$ & $(0.000569)$ & $(0.00582)$ & $(0.0135)$ & $(0.00829)$ & $(0.00925)$ & $(0.00633)$ \\
\hline \multirow[t]{2}{*}{ young $_{i t}$} & $-0.480^{* * *}$ & -0.0718 & $-1.916^{* * *}$ & 0.242 & -0.848 & -0.647 & -1.308 \\
\hline & $(0.0741)$ & $(0.0493)$ & $(0.621)$ & $(1.749)$ & $(1.256)$ & $(1.314)$ & $(1.160)$ \\
\hline \multirow[t]{2}{*}{ Constant } & $15.92^{* * *}$ & $5.317^{* * *}$ & $38.49^{* * *}$ & 20.88 & 24.17 & 22.03 & $23.46^{*}$ \\
\hline & $(1.259)$ & $(0.793)$ & $(8.074)$ & $(22.20)$ & $(15.71)$ & $(16.46)$ & $(14.16)$ \\
\hline Observations & 5,276 & 5,276 & 5,276 & 5,276 & 5,276 & 5,276 & 5,267 \\
\hline R-squared & 0.334 & 0.725 & 0.018 & 0.019 & 0.014 & 0.015 & 0.013 \\
\hline No of units & 278 & 278 & 278 & 278 & 278 & 278 & 278 \\
\hline
\end{tabular}

Robust standard errors clustered by municipality. Standard errors in parentheses. Significance level for which the null hypothesis is rejected: ***1\%, **5\% and $* 10 \%$.

All regressions include time dummies.

\subsection{Spatial Impacts}

We also study the existence of spatial impacts in wind investment. When power is installed in a given municipality, neighboring municipalities might benefit if they can commute for work or migrate, or because additional demand for their goods and services boosts local economy. If mobility is low, however, a displacement of benefits and activities might take away from neighboring municipalities' economic development. We study which effect prevails.

Table 5 presents the results for spatial analysis, using the four distance decay matrices. We focus on the construction and manufacturing phase, as it is the only one where significant results were found. ${ }^{24}$ The main variable of interest is power $_{j t+1}$, measuring installed power in neighboring municipalities that starts producing in the following year. In Column (1) the variable power $_{j t+1}$ includes as neighbors all other municipalities, with their weight varying in inverse proportion to their distance, and columns (2)-(4) consider as neighbors only municipalities that are, respectively, 30, 50, and $100 \mathrm{~km}$ apart, again with weights in inverse proportion to their distance.

\footnotetext{
${ }^{24}$ Results for the maintenance phase are available from the authors.
} 
The results show that there is only a significant impact in terms of a reduction in unemployment in a given municipality when investment is made in municipalities less than $30 \mathrm{~km}$ away (10\% significance level). The effect is very large: an increase in installed power in neighboring municipalities of 1MW per capita decreases unemployment in municipality $i$ by 171 percentage points. The fact that effects are only significant at $30 \mathrm{~km}$ or less seems to indicate an impact through commuting to work, but not effects through migration for work purposes.

Table 5: Neighboring effects

\begin{tabular}{|c|c|c|c|c|}
\hline & (1) & $(2)$ & (3) & (4) \\
\hline Matrices & All & $30 \mathrm{~km}$ & $50 \mathrm{~km}$ & $100 \mathrm{~km}$ \\
\hline power $_{i t+1}$ & $\begin{array}{c}-0.0489^{* * *} \\
(0.0128)\end{array}$ & $\begin{array}{c}-0.0462^{* * *} \\
(0.0119)\end{array}$ & $\begin{array}{c}-0.0463^{* * *} \\
(0.0118)\end{array}$ & $\begin{array}{c}-0.0501^{* * *} \\
(0.0129)\end{array}$ \\
\hline power $_{j t+1}$ & $\begin{array}{c}0.231 \\
(0.299)\end{array}$ & $\begin{array}{c}-0.171^{* *} \\
(0.0719)\end{array}$ & $\begin{array}{l}-0.221 \\
(0.169)\end{array}$ & $\begin{array}{c}0.108 \\
(0.361)\end{array}$ \\
\hline$\Delta G D P r e g_{i t-1}$ & $\begin{array}{l}-0.0227 \\
(0.0166)\end{array}$ & $\begin{array}{l}-0.0216 \\
(0.0163)\end{array}$ & $\begin{array}{l}-0.0215 \\
(0.0163)\end{array}$ & $\begin{array}{l}-0.0233 \\
(0.0167)\end{array}$ \\
\hline expend $_{i t-1}$ & $\begin{array}{c}-0.293 \\
(0.244)\end{array}$ & $\begin{array}{c}-0.294 \\
(0.244)\end{array}$ & $\begin{array}{l}-0.294 \\
(0.244)\end{array}$ & $\begin{array}{c}-0.292 \\
(0.244)\end{array}$ \\
\hline denspop $_{i t}$ & $\begin{array}{c}-0.000913^{*} \\
(0.000519)\end{array}$ & $\begin{array}{c}-0.000921^{*} \\
(0.000516)\end{array}$ & $\begin{array}{c}-0.000920^{*} \\
(0.000516)\end{array}$ & $\begin{array}{c}-0.000915^{*} \\
(0.000519)\end{array}$ \\
\hline young $_{i t}$ & $\begin{array}{l}-0.229^{* *} \\
(0.0995)\end{array}$ & $\begin{array}{c}-0.232^{* *} \\
(0.0999)\end{array}$ & $\begin{array}{c}-0.232^{* *} \\
(0.100)\end{array}$ & $\begin{array}{c}-0.227^{* *} \\
(0.100)\end{array}$ \\
\hline Constant & $\begin{array}{c}10.16^{* * *} \\
(1.662)\end{array}$ & $\begin{array}{c}10.21^{* * *} \\
(1.667)\end{array}$ & $\begin{array}{c}10.21^{* * *} \\
(1.668)\end{array}$ & $\begin{array}{c}10.15^{* * *} \\
(1.671)\end{array}$ \\
\hline Observations & 5,276 & 5,276 & 5,276 & 5,276 \\
\hline R-squared & 0.578 & 0.579 & 0.578 & 0.578 \\
\hline Number of units & 278 & 278 & 278 & 278 \\
\hline
\end{tabular}

Robust standard errors clustered by NUTS3 region. SE in parentheses. Sig. level for which null hypothesis is rejected: *** $1 \%,{ }^{*} 5 \%$ and $* 10 \%$.

All regressions include time dummies.

\subsection{Local public finance}

During the first year of production, and in subsequent years, no significant impacts in total municipality employment were found. It is possible that this is the result solely of the fact that the maintenance and operations phase is less labor demanding (ILO, 2011), or due to the fact that this phase requires specific skilled labor (for example electrical and computer engineers) that is not available at the local level. However, it is also possible that the short lived effects on employment are due to investments in wind energy that are too small to have a lasting 
impact for the local economy. In order to understand whether this is the case, and in the absence of a municipality-level GDP measure, we focus on local governments' revenues. We expect the development of a wind plant in Portugal to lead to an increase in local governments revenues because developers will often pay to use land that belongs to the municipality, they can be subject to municipal taxes, and, additionally, they are required to pay the municipality $2.5 \%$ of their revenue. We thus expect wind energy investment to have a positive impact over municipalities' finances.

We estimate the impact of wind energy investment in total revenues and some of its components as well as total expenditures. Descriptive statistics of all these variables and a graph depicting the annual sum of real revenues per capita across municipalities, as well as the annual sum of installed power, are presented in Appendix C (Table C.1 and Figure C). Own revenues are all municipality revenues with the exception of transfers from the central government, which are not expected to be impacted by wind energy investment. Sales of goods and services, property revenues and direct and indirect taxes are current revenues and capital sales are capital revenues. All dependent variables are logged.

The estimation includes dummies for the year before the wind park starts producing power $_{i t+1}$, to account for the construction period, and the year before that power $_{i t+2}$, to account for activities taking place before that, such as land sales. Finally, Apower ${ }_{i t}$ measures lasting impacts of wind power investment once the park starts producing. We control for economic variables, namely unemployment levels and the lagged growth of regional GDP, as well as demographic variables, specifically population density and the percentage of young population.

Table 6 presents the results of this analysis. In columns (1)-(7) we investigate impacts in total revenue and its components and in column (8) resulting impacts in total spending.

We find that there are small but sustained positive impacts on total revenues. The coefficient measuring increases in installed and operating wind energy $\left(\right.$ Apower $\left._{i t}\right)$ is positive and statistically significant at a $1 \%$ significance level. Specifically, we find that a $1 \mathrm{KW}$ per capita increase in operating capacity generates a $0.72 \%$ increase in per capita municipal revenues, or of around 7.7 euros. ${ }^{25}$ Significant increases in total expenditures are also visible two years before the new power goes into functioning but not in the year immediately before.

Unpacking this result, we find a strong and significant impact of wind energy investment at all stages on municipality generated revenues (own revenues). An increase of $1 \mathrm{KW}$ per capita in total power installed increases own revenues by $1.7 \%$. Further unpacking these effects, we turn

\footnotetext{
${ }^{25}$ Taking into account the average municipal population, this means that the impact of an extra 1MW of energy operating in a given municipality increases municipal revenue by around 20 cents per capita.
} 


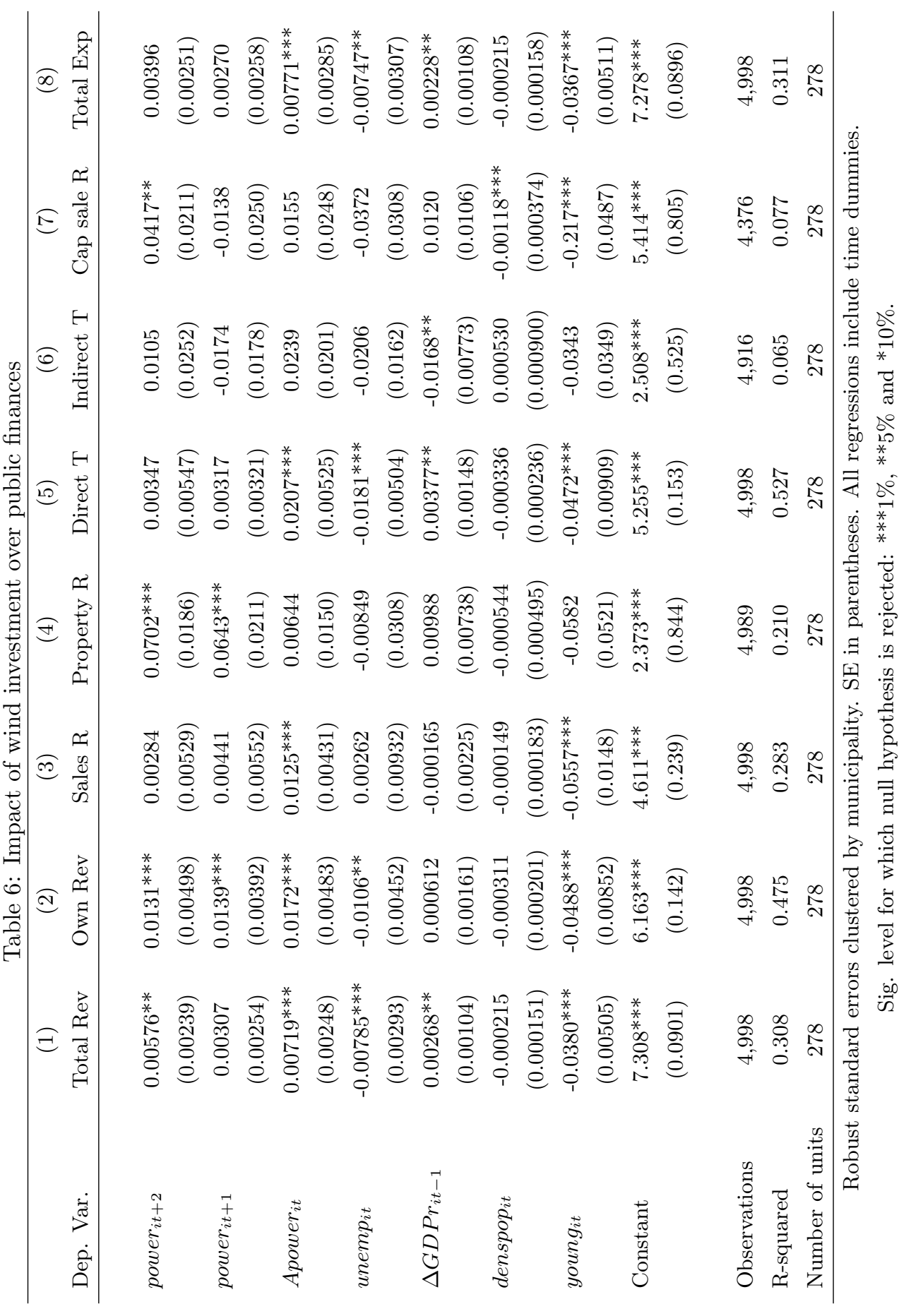


to current revenues. We find a positive effect of installed and operating wind energy on revenues from sales of goods and services. This is because wind energy developers pay $2.5 \%$ of their revenues to the municipality. Revenues from property, for example from renting municipality owned property, increase only in the period before wind energy goes into functioning. Revenues from direct taxes also increase with installed and operating capacity because wind energy developers pay the municipal tax on corporate income (derrama) and the municipal property tax (Imposto Municipal sobre Imoveis). We find no impact on indirect tax revenues, which would take place for example if investment in wind generated increased demand for licenses and other fees by firms. Finally, turning to capital revenues, we find a positive impact on revenues from the sale of capital goods on the year before construction. This is likely to be due to wind energy developers buying municipality owned land in order to install wind power.

The last column shows that the impact in revenues translates into an increase in expenditures once the wind energy installed starts operating, but not in the years before. Results show a 1KW per capita increase in installed and operating wind energy increases expenditures by $0.77 \%$, or 8.2 per capita, slightly larger than the effect on total revenues.

\section{Conclusion}

The main aim of this paper is to identify the existence, magnitude, duration, and distribution of local employment effects of wind power development. We perform an econometric analysis for a panel of all the 278 Portuguese mainland municipalities for the years between 1997 and 2017. We study the impact of the installation of wind power in a given municipality on its unemployment rate, and distinguish between the construction and installation phase, and the operations and maintenance phase. We find investment in wind power has a significant and negative impact on local unemployment during the construction phase. In particular, we estimate that a $1 \mathrm{KW}$ increase in installed power per capita leads to an average of half a percentage point decrease in unemployment rates. Based on the average population of municipalities and average unemployment rates, this translates into around 0.3 jobs per MW installed. Our results show no evidence of any effect during the operations and maintenance phases.

We then focus on differentiated impacts by gender and on skilled and unskilled employment, by investigating impacts on workers with different education levels. We find the negative effect on unemployment rates is only present for male workers and workers without a university degree, consistent with construction work. The short run increases in overall municipality employment 
during the construction phase of wind parks are thus likely caused by a direct increase in demand for labor due to the construction of the parks, rather than wind energy development spilling over to other sectors in a municipality. We further investigate the possibility of local spillovers between municipalities. Development in one region may affect employment in another through migration, if job seekers find it optimal to move in search of employment, or indirect economic impacts, like the increase in demand for goods and services in neighboring municipalities. We use a distance decay matrix to address possible local spillovers, such that geographically closer municipalities have a higher impact on each other. We find only an effect for municipalities that are $30 \mathrm{~km}$ or less from each other. This indicates migration does not seem to play an important role, but rather commuting for work does.

Our findings offer an insight on local labor market effects of incentive policies for renewable investment. If policy makers wish to increase benefits to local labor markets, there might be a case for targeting education and skill development towards the needs of this market, in order to fully take advantage of possible local labor benefits. If effects are not visible during the operating life of wind parks, this might indicate that a mismatch of skills requires wind park developers to import labor. What is more, we find that sustained increases in local governments' revenues did not translate into gains in employment, for example through an increase in public spending. While further investigation is needed for a complete understanding of the lack of sustained impact on employment during this phase, our results present for the first time a clear evaluation of the overall net impact of wind power investment in local level employment in Portugal, a country where large investment was made.

\section{References}

Anselin, L. (1988): Spatial econometrics: methods and models, vol. 4, Springer.

Bento, N. And M. Fontes (2014): "Mechanisms that accelerate the diffusion of renewable technologies in new markets: Insights from the wind industry in Portugal," dinâmia'cetWorking Papers.

Brown, J. P., J. Pender, R. Wiser, E. Lantz, And B. Hoen (2012): "Ex post analysis of economic impacts from wind power development in US counties," Energy Economics, 34, $1743-1754$. 
Casadinho, C. S. (2014): "Base de dados do potencial eólico em Portugal Continental," Ph.D. thesis, Universidade de Lisboa.

Cliff, A. And J. Ord (1981): Spatial Processes: Models \& Applications, Pion.

Costa, H., L. Gonçalves Veiga, and M. Portela (2015): "Interactions in Local Governments' Spending Decisions: Evidence from Portugal," Regional Studies, 49, 1441-1456.

De Silva, D. G., R. P. McComb, And A. R. Schiller (2016): "What blows in with the wind?" Southern Economic Journal, 82, 826-858.

Deloitte (2009): "Impacto Macroeconómico do Sector das Energias Renovveis em Portugal," Tech. rep., Deloitte.

DGAL (1986-2017): "Finanças Municipais," Tech. rep., Direção Geral das Autarquias Locais, Lisbon.

e2P Endogenous Energies of Portugal (2017a): "Parques Eólicos em Portugal - Wind Farms in Portugal," .

_ (2017b): "Website e2p Endogenous Energies of Portugal," .

GibBons, S. (2015): "Gone with the wind: Valuing the visual impacts of wind turbines through house prices," Journal of Environmental Economics and Management, 72, 177-196.

Hartley, P. R., K. B. Medlock III, T. Temzelides, and X. Zhang (2015): "Local employment impact from competing energy sources: Shale gas versus wind generation in Texas," Energy Economics, 49, 610-619.

ILO (2011): "Investment in renewable energy generates jobs. Supply of skilled workforce needs to catch up. Research Brief." Tech. rep., International Labor Organization.

INE (2015): "Estatsticas do Emprego 2014," Tech. rep., Statistics Portugal - Instituto Nacional de Estatistica.

InGLESI-Lotz, R. (2016): "The impact of renewable energy consumption to economic growth: A panel data application," Energy Economics, 53, 58-63.

Lang, C., J. J. Opaluch, and G. Sfinarolakis (2014): "The windy city: Property value impacts of wind turbines in an urban setting," Energy Economics, 44, 413-421. 
Peña, I., I. L. Azevedo, And L. A. F. M. Ferreira (2017): "Lessons from wind policy in Portugal," Energy Policy, 103, 193-202.

Ragwitz, M., W. Schade, B. Breitschopf, R. Walz, N. Helfrich, M. Rathmann, G. Resch, C. Panzer, T. Faber, R. HaAs, Et Al. (2009): "The impact of renewable energy policy on economic growth and employment in the European Union," Brussels, Belgium: European Commission, DG Energy and Transport.

Sunak, Y. and R. Madlener (2016): "The impact of wind farm visibility on property values: A spatial difference-in-differences analysis," Energy Economics, 55, 79-91.

XiA, F. AND F. Song (2017a): "Evaluating the economic impact of wind power development on local economies in China," Energy Policy, 110, 263-270.

(2017b): "The uneven development of wind power in China: Determinants and the role of supporting policies," Energy Economics, 67, 278-286.

\section{Appendix}

\section{A Data description}

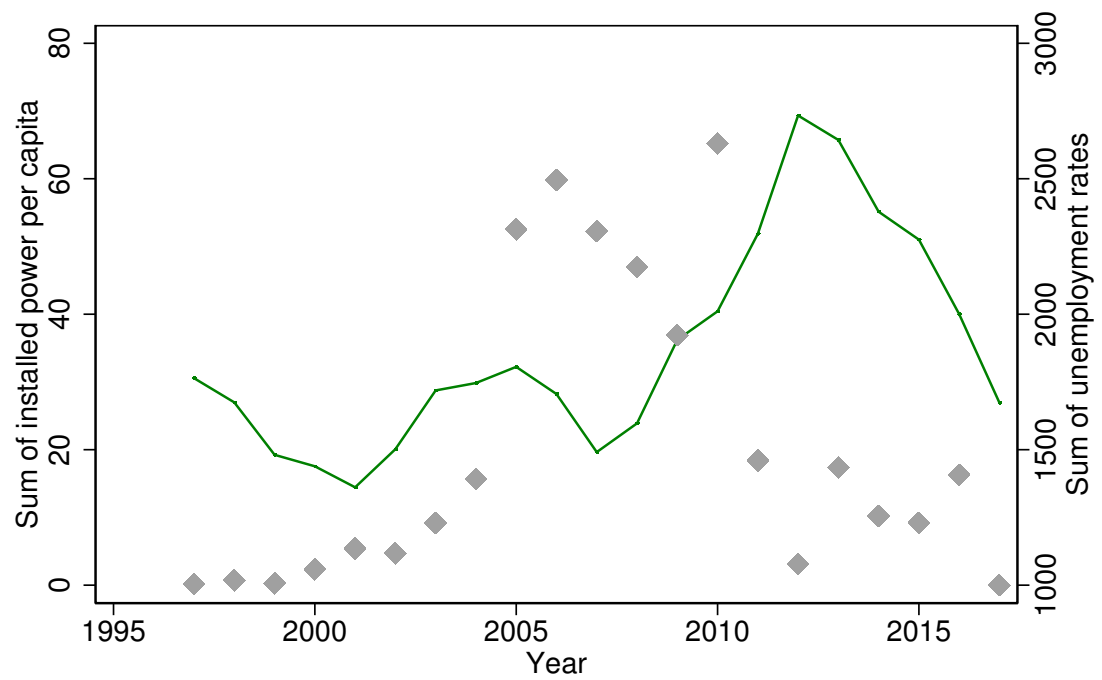

Sum of unemployment rates

Sum of installed power per capita

Figure A.1: Total new installed power and unemployment 


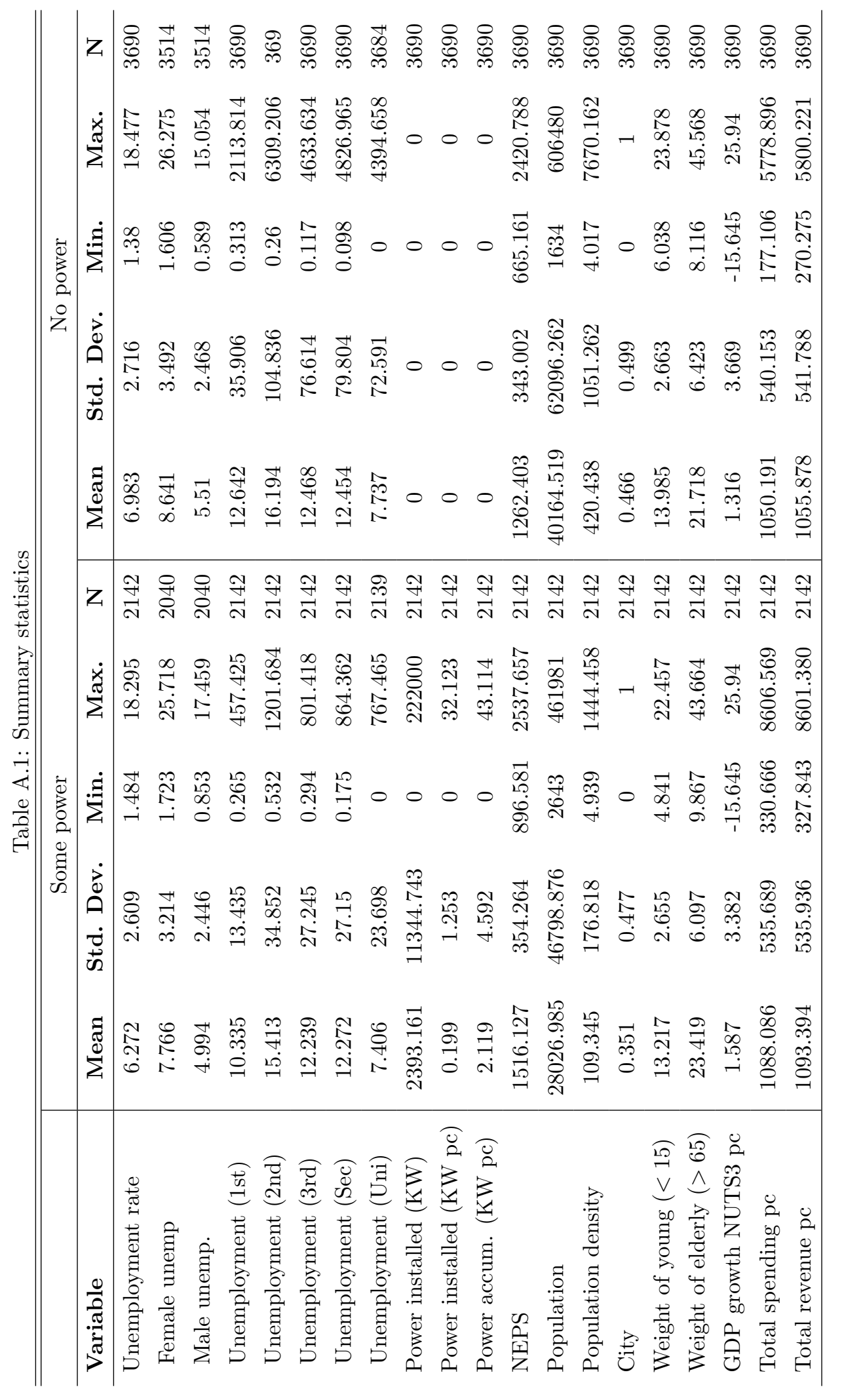




\section{B Further results}

Table B.1: Further testes to baseline specification

\begin{tabular}{|c|c|c|c|c|c|}
\hline & (1) & $(2)$ & (3) & (4) & (5) \\
\hline VARIABLES & $\mathrm{FE}$ & $\mathrm{FE}$ & $\mathrm{FE}$ & $\mathrm{FE}$ & $\mathrm{FE}$ \\
\hline power $_{i t+1}$ & $\begin{array}{c}-0.0495^{* * *} \\
(0.0151)\end{array}$ & $\begin{array}{c}-0.0490^{* * *} \\
(0.0157)\end{array}$ & $\begin{array}{c}-0.0407^{* * *} \\
(0.0146)\end{array}$ & $\begin{array}{c}-0.0406^{* * *} \\
(0.0146)\end{array}$ & $\begin{array}{c}-0.0460^{* * *} \\
(0.0157)\end{array}$ \\
\hline power $_{i t}-5.55 \mathrm{e}-05$ & $\begin{array}{c}0.000682 \\
(0.0241)\end{array}$ & $(0.0243)$ & & -0.0103 & $(0.0189)$ \\
\hline Apower $_{i t}$ & & & $\begin{array}{c}0.0173 \\
(0.0185)\end{array}$ & $\begin{array}{l}0.00755 \\
(0.0248)\end{array}$ & \\
\hline Apower $_{i t-1}$ & & & & $\begin{array}{c}0.0109 \\
(0.0256)\end{array}$ & \\
\hline power $_{i t-1}$ & $\begin{array}{c}-0.000252 \\
(0.0136)\end{array}$ & $\begin{array}{c}-0.000592 \\
(0.0138)\end{array}$ & & & \\
\hline power $_{i t-2}$ & & $\begin{array}{c}0.0103 \\
(0.0284)\end{array}$ & & & \\
\hline power $_{i t+2}$ & & & & & $\begin{array}{l}-0.0182 \\
(0.0164)\end{array}$ \\
\hline Observations & 5,276 & 4,998 & 5,276 & 5,276 & 4,998 \\
\hline R-squared & 0.578 & 0.602 & 0.578 & 0.578 & 0.597 \\
\hline Number of units & 278 & 278 & 275 & 275 & 278 \\
\hline
\end{tabular}

Robust standard errors clustered by municipality. SE in parentheses.

Null hypothesis is rejected: $* * * 1 \%, * * 5 \%$ and $* 10 \%$

All regressions include time dummies and all baseline control variables. 


\section{Summary statistics: Revenues}

Table C.1: Summary statistics

\begin{tabular}{lccccc}
\hline \multicolumn{1}{c}{ Variable } & Mean & Std. Dev. & Min. & Max. & N \\
\hline Total Revenues pc & 1069.657 & 539.903 & 270.275 & 8601.380 & 5832 \\
Own Revenues pc & 324.218 & 204.789 & 42.069 & 2713.208 & 5832 \\
Revenue Sale Goods Services pc & 86.996 & 66.53 & 0.004 & 691.193 & 5832 \\
Property Revenues pc & 27.161 & 35.101 & 0 & 621.794 & 5832 \\
Direct Tax Revenues pc & 152.168 & 130.791 & 6.225 & 1470.485 & 5832 \\
Indirect Tax Revenues pc & 11.43 & 21.635 & -4.098 & 554.811 & 5832 \\
Revenue Capital Sale pc & 13.162 & 36.925 & -0.206 & 1771.438 & 5832 \\
Total Expenditures pc & 1064.109 & 538.782 & 177.106 & 8606.569 & 5832 \\
\hline
\end{tabular}

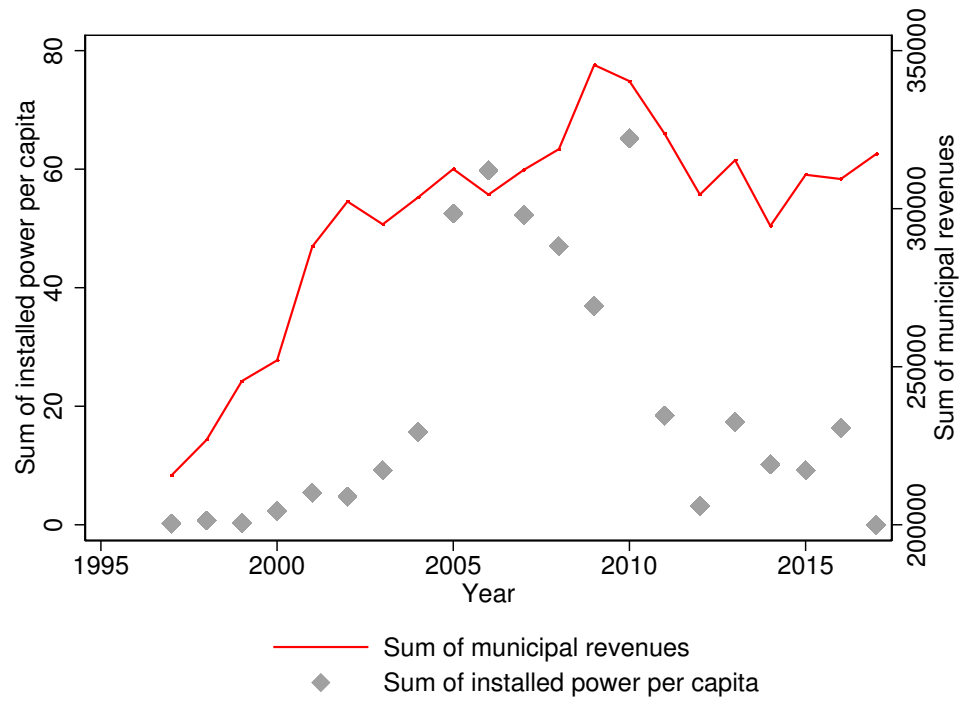

Figure C.1: Total new installed power and unemployment 